\title{
PROFESI KEGURUAN
}

\author{
Aulia \\ Email: 2010111320010@mhs.ulm.ac.id \\ Program Studi Pendidikan Sejarah Fakultas Keguruan dan Ilmu Pendidikan \\ Universitas Lambung Mangkurat \\ Banjarmasin
}

\begin{abstract}
Abstrak
Guru adalah salah satu unsur manusia dalam proses pendidikan di sekolah sekaligus memegang tugas dan fungsi ganda, yaitu sebagai pengajar dan sebagai pendidik. Sebagai pengajar guru hendaknya mampu menuangkan sejumlah bahan pelajaran ke dalam otak anak didik, sedangkan sebagai pendidik guru diharapkan dapat membimbing dan membina anak didik agar menjadi manusia susila yang cakap, aktif, kreatif, dan mandiri (Deden, 2011).

Setiap profesi memiliki kode etik masing-masing, begitu pula dengan guru. Kode etik suatu profesi adalah norma-norma yang harus diindahkan oleh setiap anggota profesi dalam melaksanakan tugas profesinya dan dalam hidupnya di masyarakat. Norma-norma tersebut berisi petunjuk-petunjuk bagi anggota profesi tentang bagaimana mereka melaksanakn profesinya dan larangan-larangan, yaitu ketentuan-ketentuan tentang yang tidak boleh diperbuat atau dilaksanakan oleh mereka tidak hanay dalam melaksanakan tugas profesi mereka melainkan juga menyangkut tingkah laku anggota profesi pada umumnya dalam pergaulannya sehari-hari didalam masyarakat.
\end{abstract}

Selain itu agar dapat memberikan layanan yang optimal, diperlukan persyaratanpersyaratan dan ketentuan-ketentuan mengenai bagaimana layanan itu diberikan (kewajiban) kepada peserta didik. Sikap profesionalisme guru juga patut diperhatikan guna 
meningkatkan kinerja guru. Sikap yang baik tercermin dari pribadi yang baik pula, hal tersebut erat kaitannya dengan kompetensi guru yaitu kompetensi kepribadian. Empat kompetensii guru (kepribadian, pedagogik, sosial, dan profesional) menjadi salah satu syarat seorang guru dapat dikatakan profesional.

Berdasarkan pemaparan tersebut, kami akan membahas makalah tentang pengertian profesi, profesi keguruan dan syarat-syarat profesi keguruan, serta kode etik dan organisasi profesional keguruan.

\section{PENDAHULUAN}

\section{PENGERTIAN PROFESI}

Profesi adalah pekerjaan yang membutuhkan pelatihan dan penguasaan terhadap suatu pengetahuan khusus. Suatu profesi biasanya memiliki asosiasi profesi, kode etik, serta proses sertifikasi dan lisensi yang khusus untuk bidang profesi tersebut. Contoh profesi adalah pada bidang hukum, kedokteran, pendidikan, keuangan, militer, dan teknik.

Seseorang yang memiliki suatu profesi tertentu, disebut profesional. Walaupun begitu, istilah profesional juga digunakan untuk suatu aktivitas yang menerima bayaran, sebagai lawan kata dari amatir. Contohnya adalah petinju profesional menerima bayaran untuk pertandingan tinju yang dilakukannya, sementara olahraga tinju sendiri umumnya tidak dianggap sebagai suatu profesi.

Pada umumnya orang memberi arti yang sempit teradap pengertian profesional. Profesional sering diartikan sebagai suatu keterampilan teknis yang dimilki seseorang. Misalnya seorang guru dikatakan guru profesional bila guru tersebut memiliki kualitas megajar yang tinggi. Padahal pengertian profesional tidak sesempit itu, namun pengertiannya harus dapat dipandang dari tiga dimensi, yaitu : expert [ahli], responsibility [rasa tanggung jawab] baik tanggung jawab intelektual maupun moral, dan memiliki rasa kesejawatan.

Pengertian profesi secara leksikal ialah perkataan profesi itu ternyata mengandung berbagai makna dan pengertian. Pertama profesi itu menunjukkan dan mengungkapkan suatu kepercayaan (to profess means to trust), bahkan suatu keyakinan (to belief in) atas 
suatu kebenaran (ajaran agama) atau kredibilitas seseorang (Hornby,1962). Kedua, profesi itu dapat pula menunjukkan dan mengungkapkan suatu pekerjaan atau urusan tertentu (a particular business, Hornby, 1962 dalam Pengembangan Profesi Guru, Udin Syafrudin, 2009: 3 ).

Webster's New World Dictionary menunjukkan bahwa profesi merupakan suatu pekerjaan yang menuntut pendidikan tinggi (kepada pengembannya) dalam liberal arts atau science, dan biasanya meliputi pekerjaan mental dan bukan pekerjaan manual, seperti mengajar, keinsinyuran, mengarang, dan sebagainya; terutama kedokteran, hukum dan teknologi.

Good's Dictionary of Education mengungkapkan bahwa profesi merupakan suatu pekerjaan yang meminta persiapan specialisasi yang relatif lama di perguruan tinggi (pada pengembannya) dan diatur oleh suatu kode etika khusus.

Vollmer (1956) dalam Pengembangan Profesi Guru, Udin Syafrudin, 2009: 5 menjelaskan pendekatan kajian sosiologik, mempersepsikan bahwa profesi itu sesungguhnya hanyalah merupakan suatu jenis model atau tipe pekerjaan ideal saja, karena dalam realitasnya bukanlah hal yang mudah untuk mewujudkannya. Namun demikian, bukanlah merupakan hal yang mustahil pula untuk mencapainya asalkan ada upaya yang sungguh-sungguh kepada pencapaiannya. Proses usaha menuju kearah terpenuhinya persyaratn suatu jenis model pekerjaan ideal itulah yang dimaksudkan dengan profesionalisasi.

Bedasarkan pernyataan Vollmer yang mengimplikasikan bahwa pada dasarnya seluruh pekerjaan apapun memungkinkan untuk berkembang menuju kepada suatu jenis model profesi tertentu. Dengan mempergunakan perangkat persyaratannya sebagai acuan, maka kita dapat menandai sejauh mana suatu pekerjaan itu telah menunjukkan ciri-ciri atau sifat-sifat tertentu atau seseorang pengemban pekerjaan tersebut juga telah memiliki dan menampilkan ciri-ciri atau sifat-sifat tertentu pula yang dapat dipertanggungjawabkan secara professional (memadai persyaratan sebagai suatu profesi). Berdasarkan indikatorindikator tersebut maka selanjutnya kita dapat mempertimbangkan derajat profesionalitasnya (ukuran kadar keprofesiannya). Jika konsepsi keprofesian itu telah menjadi budaya, pandangan, paham, dan pedoman hidup seseorang atau sekelompok orang 
utau masyarakan tertentu, maka hal itu dapat mengandung makna telah tumbuh-kembang profesionalisme dikalangan orang atau masyarakat yang bersangkutan. Suatu profesi umumnya berkembang dari pekerjaan yang kemudian berkembang makin matang.

Selain itu, dalam bidang apapun profesionalisme seseorang ditunjang oleh tiga hal. Tanpa ketiga hal ini dimiliki, sulit seseorang mewujudkan profesionalismenya. Ketiga hal itu ialah keahlian, komitmen, dan keterampilan yang relefan yang membentuk sebuah segitiga sama sisi yang ditengahnya terletak profesionalisme. Ketiga hal itu pertama-tama dikembangkan melalui pendidikan pra-jabatan dan selanjutnya ditingkatkan melalui pengalaman dan pendidikan/latihan dalam jabatan. Karena keahliannya yang tinggi maka seorang professional dibayar tinggi. “ well educated, well trained, well paid”, adalah salah satu prinsip profesionalisme. Terdapat beberapa istilah yang berkaitan dengan profesi. Menurut Sanusi et.al ( 1991:19 ) dalam Pengembangan Profesi Guru, Udin Syafrudin, 2009: 6 menjelaskan ada 5 konsep mengenai hal tersebut:

1. Profesi adalah suatu jabatan atau pekerjaan yang menuntut keahlian para anggotanya. Artinya, ia tidak bias dilakukan oleh sembarang orang yang tidak dilatih dan tidak disiapkan secara khusus untuk melakukan pekerjaan itu. keahlian diperoleh melalui apa yang disebut profesionalisasi, yang dilakukan baik sebelum seseorang menjalani profesi itu ( pendidikan/latihan pra-jabatan) maupun setelah menjalani suatu profesi ( in-service training ). Diluar pengertian ini, ada beberapa ciri profesi khususnya yang berkaitan dengan profesi kependidikan.

2. Professional menunjuk pada dua hal. Pertama orang yang menyandang suatu profesi, misalnya “ Dia seorang profesional”. Kedua, penampilan seseorang dalam melakukan pekerjaannya yang sesuai dengan profesinya. Pengertian kedua ini, professional dikontraskan dengan " non-profesional" atau " amatir".

3. Profesionalisme menunjuk kepada komitmen para anggota suatu profesi untuk meningkatkan kemampuan profesionalnya dan terus-menerus mengembangkan strategi-strategi yang digunakannya dalam melakukan pekerjaan yang sesuai dengan profesinya. 
4. Profesionalitas mengacu kepada sikap para anggota profesi terhadap profesinya serta derajat pengetahuan dan keahlian yang mereka miliki dalam rangka melakukan pekerjaannya.

5. Profesionalisasi menunjukkan pada proses peningkatan kualifikasi maupun kemampuan para anggota profesi dalam mencapai kriteria yang standar dalam penampilannya sebagai anggota suatu profesi. Profesionalisasi pada dasarnya merupakan serangkaian proses pengembangan professional ( professional development) baik dilakukan melalui pendidikan/latihan "pra-jabatan" maupun “dalam-jabatan”. Oleh karena itu, profesionalisasi merupakan proses yang life-long dan never-ending, secepat seseorang telah menyatakan dirinya sebagai warga suatu profesi.

\section{PENGERTIAN PROFESI KEGURUAN}

Dalam sumber lain, Soetjipto dan kawan kawan dalam buku Profesi Keguruan, pada halaman 14 sampai dengan 29, profesi diungkapkan oleh Ornstein dan Levine (dalam Soetjipto dan Raflis Kosasih, Profesi Keguruan: 15) menyatakan bahwa profesi itu adalah jabatan yang sesuai dengan pengertian profesi dibawah ini:

a. Melayani masyarakat, merupakan karier yang akan dilaksanakan sepnjang hayat ( tidak berganti-ganti pekerjaan).

b. Memerlukan bidang ilmu dan keterampilan tertentu diluar jangkauan khalayak ramai (tidak setiap orang dapat melakukannya).

c. Menggunakan hasil penelitian dan aplikasi dari teori ke praktek (teori baru dikembangkan dari hasil penelitian).

d. Memerlukan pelatihan khusus dengan waktu yang panjang.

e. Terkendali berdasarkan lisensi baku dan atau mempunyai persyaratan masuk (untuk menduduki jabatan tersebut memerlukan izin tertentu atau ada persyaratan khusus yang ditentukan untuk dapat mendudukinya).

f. Otonomi dalam membuat keputusan tentang ruang lingkup kerja tertentu (tidak diatur oleh orang luar.

g. Menerima tanggung jawab terhadap keputusan yang diambil dan unjuk kerja yang ditampilkan yang berhubungan dengan layanan yang diberikan (langsung 
bertanggung jawab terhadap apa yang diputuskannya, tidak dipindahkan atasan atau instansi yang lebih tinggi). Mempunyai sekumpulan unjuk kerja yang baku.

h. Mempunyai komitmen terhadap jabatan dan klien; dengan penekanan terhadap layanan yang diberikan.

i. Menggunakan administrator untuk memudahkan profesinya, relative bebas dari supervise dalam jabatan (misalnya dokter memakai tenaga administrasi untuk mendata klien, sementara tidak ada supervise dari luar terhadap pekerjaan dokter sendiri).

j. Mempunyai organisasi yang diatur oleh anggota profesi sendiri.

k. Mempunyai asosiasi profesi dan atau kelompok 'elit' untuk mengetahui dan mengakui keberhasilian anggotanya (keberhasilan tugas dokter dievaluasi dan dihargai oleh organisasi Ikatan Dokter Indonesia (IDI), bukan oleh Departemen Kesehatan).

1. Mempunyai kode etik untuk menjelaskan hal-hal yang meragukan atau menyangsikan yang berhubungan dengan layanan yang diberikan.

m. Mempunyai kadar kepercayaan yang tinggi dari public dan kepercayaan diri setiap anggotanya (anggota masyarakat selalu meyakini dokter lebih tahu tentang penyakit pasien yang dilayaninya).

n. Mempunyai status social dan ekonomi yang tinggi bila disbanding dengan jabatan lainnya).

Tidak jauh berbeda dengan ciri diatas, sanusi et al. (1991), mengutarakan ciri-ciri utama suatu profesi itu sebagai berikut (dalam Soetjipto dan kawan kawan, Profesi Keguruan; 17),

a. Suatu jabatan yang memiliki fungsi dan signifikan social yang menentukan (crusial).

b. Jabatan yang menuntut keterampilan/ keahlian tertentu.

c. Keterampilan/keahlian yang dituntut jabatan itu didapat melalui pemecahan masalah dengan menggunakan teori dan metode ilmiah.

d. Jabatan itu berdasarkan pada batang tubuh disiplin ilmu yang jelas, sistematik, eksplisit, yang bukan hanya sekedar pendapat khalayak umum. 
e. Jabatan itu memerlukan pendidikan tingkat perguruan tinggi dengan waktu yang cukup lama.

f. Profesi pendidikan untuk jabatan itu jga merupakan aplikasi dan sosialisasi nilainilai professional itu sendiri.

g. Dalam memberikan layanan kepada masyarakat, anggota profesi itu berpegang teguh pada kode etik yang dikontrol oleh organsasi profesi.

h. Tiap anggota profesi mempunyai kebebasan dalam memberikan judgement terhadap permasalahan profesi yang dihadapinya.

i. Dalam prakteknya melayani masyarakat, anggota profesi otonom dan bebas dari campur tangan orang luar.

j. Jabatan ini mempunyai prestise yang tinggi dalam masyarakat, dan oleh karenanya memperoleh imbalan yang tinggi pula.

Bila kita bandingkan kriteria yang dipakai sanisi et al. ini dengan kriteria Ornstein dan Levine yang dibicarakan lebih dahulu, dapat kita simpulkan bahwa keduanya hampir mirip, dan saling melengkapi, dan oleh karenanya dapat kita pakai sebagai pedoman dalam pembicaraan selanjutnya.

Kalau kita pakai acuan ini maka jabatan pedagang, penyanyi, penari, serta tukang korang yang disebut pada bagian pertama jelas bukan profesi. Tetapi yang akan kita bicarakan selanjutnya adalah jabatan.

Blog: $\quad$ https://ilmu-pendidikan.net/profesi-kependidikan/guru/hak-dan-kewajibanprofesi-seorang-guruhttps://ilmu-pendidikan.net/profesi-kependidikan/guru/hak-dankewajiban-profesi-seorang-guru

\section{PERAN GURU SEBAGAI SEBUAH PROFESI}

Jabatan guru dapat dikatakan sebuah profesi karena menjadi seorang guru dituntut suatu keahlian tertentu (meng-ajar, mengelola kelas, merancang peng-ajaran) dan dari pekerjaan ini se- seorang dapat memiliki nafkah bagi kehidupan selanjutnya. Hal ini berlaku sama pada pekerjaan lain. Namun da-lam perjalanan selanjutnya, mengapa profesi guru menjadi berbeda dari pekerjaan lain. Menurut artikel "The Limit of Teaching Proffesion," profesi guru termasuk ke dalam profesi khusus _ selain dokter, penasihat 
hukum, pastur. Kekhususannya adalah bahwa hakekatnya terjadi dalam suatu bentuk pelayanan manusia atau masyarakat. Orang yang menjalankan profesi ini hendak-nya menyadari bahwa ia hidup dari padanya, itu haknya; ia dan keluarga-nya harus hidup _ akan tetapi hakikat profesinya menuntut agar bukan nafkah hidup itulah yang menjadi motivasi utamanya, melainkan kese- diaannya untuk melayani sesama.Di lain pihak profesi guru juga disebut sebagai profesi yang luhur. Dalam hal ini, perlu disadari bahwa seorang guru dalam melaksanakan profesinya dituntut adanya budi luhur dan akhlak yang tinggi. Mereka (guru) dalam ke-adaan darurat dianggap wajib juga membantu tanpa imbalan yang cocok. Atau dengan kata lain hakikat profesi luhur adalah pengabdian kemanusia-an.

\section{Hak-Hak Guru}

Dalam Undang-Undang Guru dan Dosen pasal 14 ayat 1 menyatakan, bahwa dalam melaksanakan tugas keprofesionalan, guru memiliki hak sebagai berikut:

1. Memperoleh penghasilan di atas kebutuhan hidup minimum dan jaminan kesejahteraan sosial.

2. Mendapatkan promosi dan penghargaan sesuai dengan tugas dan prestasi kerja.

3. Memperoleh perlindungan dalam melaksanakan tugas dan hak atas kekayaan intelektual.

4. Memperoleh kesempatan untuk meningkatkan kompetensi.

5. Memperoleh dan memanfaatkan sarana dan prasarana pembelajaran untuk menunjang kelancaran tugas keprofesionalan.

6. Memiliki kebebasan dalam memberikan penilaian dan ikut menentukan kelulusan, penghargaan, dan/atau sanksi kepada peserta didik

7. sesuai dengan kaidah pendidikan, kode etik guru, dan peraturan perundang-undangan.

8. Memperoleh rasa aman dan jaminan keselamatan dalam melaksanakan tugas.

9. Memiliki kebebasan untuk berserikat dalam organisasi profesi.

10. Memiliki kesempatan untuk berperan dalam penentuan kebijakan pendidikan.

11. Memperoleh kesempatan untuk mengembangkan dan meningkatkan kualifikasi akademik dan kompetensi, dan/atau

12. Memperoleh pelatihan dan pengembangan profesi dalam bidangnya. 


\section{Kewajiban Guru}

Menurut UU Guru dan Dosen pasal 20, bahwa dalam melaksanakan tugas keprofesionalan, guru berkewajiban:

1. Merencanakan pembelajaran, melaksanakan proses pembelajaran yang bermutu, serta menilai dan mengevaluasi hasil pembelajaran.

2. Meningkatkan dan mengembangkan kualifikasi akademik dan kompetensi secara berkelanjutan sejalan dengan perkembangan ilmu pengetahuan, teknologi, dan seni.

3. Bertindak objektif dan tidak diskriminatif atas dasar pertimbangan jenis kelamin, agama, suku, ras, dan kondisi fisik tertentu, atau latar

4. belakang keluarga, dan status sosial ekonomi peserta didik dalam pembelajaran.

5. Menjunjung tinggi peraturan perundang-undangan, hukum, dan kode etik guru, serta nilai-nilai agama dan etika, dan

6. Memelihara dan memupuk persatuan dan kesatuan bangsa.

Cukup seimbang memang jika dilihat perbandingan antara hak dan kewajiban profesi guru. Keseimbangan antara hak dan kewajiban ini yang membuat guru mampu bekerja secara optimal dan menerima timbal balik yang pantas serta melaksanakan tugas sesuai dengan kode etik guru. Tidak ada guru yang lebih banyak hak dari pada kewajiban yang dilakukan dan begitu pula sebaliknya lebih banyak kewajiban dari pada hak yang diterima, meskipun demikian memang masih banyak saja hal ini terjadi.

Namun cukup ironis juga ketika masih banyak guru yang sudah melaksanakan kewajiban namun belum mendapatkan hak-hak yang semestinya bisa mereka dapatkan. Terutama di daerah yang jauh dari kota, selain sarana dan prasarana yang masih kurang, kesejahteraan kehidupan guru yang bisa dicapai dari penerimaan hak belum mampu dinikmati seluruh guru. Ya, memang kemerataan pendidikan di Indonesia masih belum dapat dicapai, sebuah tugas bagi seluruh masyarakat Indonesia agar hal ini dapat diwujudkan sehingga cita-cita bangsa dapat digapai melalui pendidikan yang baik.

Jurnal: https://ilmu-pendidikan.net/profesi-kependidikan/guru/hak-dan-kewajiban-profesiseorang-guru 


\section{GURU INDONESIA DAN TANTANGAN PROFESIONALISME}

Pada umumnya orang memberi arti sempit terhadap pengertian profesional. Profesional sering diartikan sebagai suatu keterampilan teknis yang dimiliki seseorang. Sedangkan pengertian kreativitas adalah mengandung arti kemampuan untuk menciptakan sesuatu yang baru dengan cara menghubungkan beberapa hal yang sudah ada dan menjadikan sesuatu hal yang baru. Jadi hubungan antara kreativitas dan sikap profesional adalah suatu keterampilan teknis yang dimiliki oleh seseorang dalam menciptakan suatu karya yang berguna bagi orang lain. Misalnya seorang guru dapat menciptakan suasana belajar yang baru yang dan lebih menarik sehingga membuat para siswa nya lebih semangat belajar atau seseorang yang menciptakan sebuah karya seni yang dapat dinikmati oleh orang lain.

Profesional sering diartikan sebagai suatu keterampilan teknis yang dimiliki seseorang. Misalnya, seorang guru dikatakan profesional bila guru itu memiliki kualitas pembelajaran yang tinggi. Padahal profesional mengandung makna yang lebih luas dari berkualitas. Selain itu profesional juga bisa diartikan sebagai kompetensi atau kemampuan seorang guru.

Konsep profesionalisme, seperti yang dikembangkan oleh hall (1968), kata tersebut banyak digunakan peneliti untuk melihat bagaimana para profesional memandang ppfesinya, yang tercermin dari sikap dan perilaku mereka. Konsep profesionalisme seperti yang dijelaskan sumardi (2010), bahwa ia memiliki lima prinsip atau muatan pokok yaitu:

Afiliasi komunitas (community affilition) yaitu menggunakan ikatan profesi sebagai acuan, termasuk di dalamnya organisasi formal atau kelompok-kelompok kolega informal sumber ide pertama pekerjaan. Melalui ikatan ini para profesional membangun kesadaran profesi.

Kebutuhan untuk mandiri (autonomy demand) merupakan suatu pandangan bahwa seseorang yang profesional harus mampu membuat kepitusan sendiri tanpa tekanan dari pihak lain (pemerintah, klien, mereka yang bukan anggota profesi). Setiap adanya campur tangan (intervensi) yang datang dari luar, dianggap sebagai hambatan terhadap kemandirian 
secara profesional. Banyak yang menginginkan pekerjaan yang memberikan hak-hak istimewa untuk membuat keputusan dan bekerja tanpa diawasi secara ketat. Rasa kemandirian dapat berasal dari kebebasan melakukan apa yang terbaik menurut yang bersangkutan dalam situasi khusus.

Keyakinan terhadap peraturan sendiri/profesi ( believe self regulation) dimaksud bahwa yang paling berwenang dalammenilai pekerjaan profesional adalah rekan sesama profesi, bukan "orang luar" yang tidak mempunyai kompetensi dalam bidang ilmu dan pekerjaan mereka.

Dedikasi pada profesu (dedication) dicerminkan dari dedikasi profesional dengan menggunakan pengetahuan dan kecakapan yang dimiliki. Keteguhan tetap untik melaksanakan pekerjaan meskipun imbalan esktrinsik dipandang kurang.

Kewajiban sosial (social obligation) merupakan pandangan tentang pentingnya profesi serta manfaat yang diperoleh baik oleh masyarakat maupun profesional karena adanya pekerjaan tersebut.

Lima prinsip tersebut menjelaskan bahwa profesionalisme mengacu pada ketentuan dalam menjalankan profesi yang telah memperoleh pengakuan dari suatu afiliasi, bersikap mandiri dalam mengambil keputusan keprofesian, memahami dan mengikuti unsur regulatif terkait profesinya, memiliki dedikasi, dan menunjukan tanggung jawab sosial dalam menjalani profesi. Dengan demikian profesionalisme pada dasarnya adalah ciri individu yang menjalankan profesi dengan memenuhi kriteria-kriteria tersebut.

Kalau kita ikuti perkembangan profesi keguruan di Indonesia, jelas bahwa pada mulanya guru-guru Indonesia diangkat dari orang-orang yang tidak berpendidikan khusus untuk memangku jabatan guru. Dalam bukunya sejarah pendidikan Indonesia, Nasution (1987) dalam Soetjipto dan Raflis Kosasih, Profesi Keguruan, 2004: 27 secara jelas melukiskan sejarah pendidikan di Indonesia terutama dalam zaman colonial Belanda, termasuk juga sejarah profesi keguruan. Guru-guru yang pada mulanya diangkat dari orangorang yang tidak dididik secara khusus menjadi guru, secara berangsu-angsur dilengkapi 
dan ditambah dengan guru-guru yang lulus dari sekolah guru (Kweekschool) yang pertama kali didirikan di Solo tahun 1852. Karena kebutuhan yang mendesak maka Pemerintah Hindia Belanda mengangkat lima macam guru, yakni : (1) Guru lulusan sekolah guru yang dianggap sebagai guru yang berwenang penuh, (2) guru yang bukan lulusan sekolah guru, tetapi lulus ujian yang diadakan untuk menjadi guru, (3) guru bantu, yakni yang lulus ujian guru bantu, (4) guru yang dimagangkan kepada seorang guru senior, yang merupakan calon guru, dan (5) guru yang diangkat karena keadaan yang amat mendesak yang beasal dari warga yang pernah mengecap pendidikan. Tentu saja yang terakhir ini sangat beragam dari satu daerah dengan daerah lainnya.

Walaupaun sekolah guru telah dimualai dan kemudian juga didirikan sekolah normal, namun mulanya bila dilihat dari kurikulumnya dapat kita katakana hany mementingkan pengetahuan yang akan diajarkan saja. Kedalamnya belum dimasukkan secara khusus kurikulum ilmu mendidik dan psikologi. Sejalan dengan pendirian sekolahsekolah yang lebih tinggi tingkatnya dari sekolah umum seperti Hollands Inlandse School (HIS), Meer Uitgebreid Lagere Onderwijs (MULO), Hogere Burgeschool (HBS), dan Algemene Middelbare School (AMS) maka secara berangsur-angsur didirikan pula lembaga pendidikan guru atau kursus-kursus untuk mempersiapkan guru-gurunga, seperti Hogere Kweekschool (HKS) untuk guru HIS dab kursus Hoofdacte (HA) untuk calon kepala sekolah (Nasution 1987).

Keadaan yang demikian berlanjut sampai zaman pendudukan jepang dan awal perang kemerdekaan, walaupun dengan nama dan bentuk lembaga pendidikan guru yang disesuaikan dengan keadaan waktu itu. Selangkah demi selangkah pendidkan guru meningkatkan jenjng kualifikasi dan mutunya, sehingga saat ini kita hanya mempunyai lembaga pendidikan guru yang tunggak, yakni Lembaga Pendidikan Tenaga Kependidikan (LPTK). Walaupun jabatan guru tidak harus disebut jbatan professional penuh, statusnya mulai membaik. Di Indonesia telah ada Persatuan Guru Republik Indonesia (PGRI) yuang mewadahi persatuan guru, dan juga mempunyai perwakilan perwakilan di DPR/MPR.

4 Kompetensi Dasar yang Harus Dimiliki Guru Profesional - Anda ingin menjadi pendidik atau seorang guru? Secara sederhana dapat diungkapkan bahwa guru adalah yang mampu menjalankan fungsi dan tugasnya menurut kriteria tertentu yang ditetapkan oleh 
pemerintah. Menurut UU No 14 tahun 2005 tentang Guru dan Dosen; seorang guru profesional harus memiliki empat kompetensi dasar dalam pendidikan. Empat kompetensi dasar ini diantaranya adalah kompetensi profesional, pedagogik, sosial, dan kompetensi kepribadian

Berikut 4 kompetensi dasar yang harus dimiliki oleh seorang guru profesional:

\section{Profesional}

Kompetensi profesional adalah kemampuan seorang guru dalam mengelola proses belajar mengajar. Kemampuan mengelola pembelajaran didukung oleh pengelolaan kelas, penguasaan materi belajar, strategi mengajar dan penggunaan media belajar.

\section{Pedagogik}

Kompetensi pedagogik berkaitan erat dengan kemampuan guru dalam memahami proses pembelajaran. Pembelajaran yang berlangsung di ruang kelas bersifat dinamis. Ini dapat terjadi karena komunikasi atau interaksi timbal balik antara guru dengan siswa dan siswa dengan siswa. Keberagaman siswa didalam kelas juga akan memerlukan keterampilan seorang guru dalam mendisain program pembelajaran.

\section{Sosial}

Kompetensi sosial adalah kemampuan guru sebagai pendidik untuk berkomunikasi dan berinteraksi yang baik dengan warga sekolah maupun warga dimana guru berada. Kemampuan sosial ini dapat dilihat melalui pergaulan sosial guru dengan siswa, rekan sesama guru maupun dengan masyarakat dimana ia berada.

\section{Kepribadian}

Dalam menjalankan tugas dan fungsinya, seorang guru harus menunjukkan sikap dan kepribadian yang baik. Guru yang patut ditiru merupakan filosofi yang menunjukkan kemampuan kepribadian. Ditiru karena guru diyakini mempunyai ilmu yang bermanfaat bagi kelangsungan hidup siswanya. Seorang guru ditiru karena pada diri guru terdapat sikap dan pribadi yang baik. 
Jurnal: https://www.sman1tualang.sch.id/news/4-kompetensi-dasar-yang-harus-dimilikiguru-profesional.html

\section{SIMPULAN}

Melayani masyarakat, merupakan karier yang akan dilaksanakan sepnjang hayat. Memerlukan pelatihan khusus dengan waktu yang panjang. Menerima tanggung jawab terhadap keputusan yang diambil dan unjuk kerja yang ditampilkan yang berhubungan dengan layanan yang diberikan. Mempunyai sekumpulan unjuk kerja yang baku.Mempunyai organisasi yang diatur oleh anggota profesi sendiri. Mempunyai kode etik untuk menjelaskan hal-hal yang meragukan atau menyangsikan yang berhubungan dengan layanan yang diberikan. Mempunyai kadar kepercayaan yang tinggi dari public dan kepercayaan diri setiap anggotanya. Suatu jabatan yang memiliki fungsi dan signifikan social yang menentukan. Jabatan yang menuntut keterampilan/ keahlian tertentu. Keterampilan/keahlian yang dituntut jabatan itu didapat melalui pemecahan masalah dengan menggunakan teori dan metode ilmiah. Jabatan itu berdasarkan pada batang tubuh disiplin ilmu yang jelas, sistematik, eksplisit, yang bukan hanya sekedar pendapat khalayak umum. Jabatan itu memerlukan pendidikan tingkat perguruan tinggi dengan waktu yang cukup lama. Dalam memberikan layanan kepada masyarakat, anggota profesi itu berpegang teguh pada kode etik yang dikontrol oleh organsasi profesi. Tiap anggota profesi mempunyai kebebasan dalam memberikan judgement terhadap permasalahan profesi yang dihadapinya. Jabatan ini mempunyai prestise yang tinggi dalam masyarakat, dan oleh karenanya memperoleh imbalan yang tinggi pula. Bila kita bandingkan kriteria yang dipakai. ini dengan kriteria Ornstein dan Levine yang dibicarakan lebih dahulu, dapat kita simpulkan bahwa keduanya hampir mirip, dan saling melengkapi, dan oleh karenanya dapat kita pakai sebagai pedoman dalam pembicaraan selanjutnya. Kalau kita pakai acuan ini maka jabatan pedagang, penyanyi, penari, serta tukang korang yang disebut pada bagian pertama jelas bukan profesi. Tetapi yang akan kita bicarakan selanjutnya adalah jabatan. 


\section{REFERENSI}

Efendi, I., Prawitasari, M., \& Susanto, H. (2021). Implementasi Penilaian Pembelajaran Pada Kurikulum 2013 Mata Pelajaran Sejarah. Prabayaksa: Journal of History Education, 1(1), 21-25.

Susanto, H. (2020). Profesi Keguruan. Banjarmasin: FKIP Universitas Lambung Mangkurat.

Susanto, H., \& Akmal, H. (2018). Efektivitas Penggunaan Aplikasi Pembelajaran Berbasis Mobile Smartphone Sebagai Media Pengenalan Sejarah Lokal Masa Revolusi Fisik Di Kalimantan Selatan Pada Siswa Sekolah Menengah Atas. HISTORIA: Jurnal Program Studi Pendidikan Sejarah, 6(2), 197-206.

Susanto, H., Irmawati, I., Akmal, H., \& Abbas, E. W. (2021). Media Film Dokumenter Masuknya Islam Ke Nusantara dan Pengaruhnya Terhadap Keterampilan Berpikir Kritis Siswa. HISTORIA: Jurnal Program Studi Pendidikan Sejarah, 9(1).

Syaharuddin, S., \& Susanto, H. (2019). Sejarah Pendidikan Indonesia (Era Pra Kolonialisme Nusantara sampai Reformasi). Banjarmasin: FKIP Universitas Lambung Mangkurat.

Soetjipto(dalam Soetjipto dan kawan kawan, Profesi Keguruan; 17)

Ornstein dan Levine (dalam Soetjipto dan Raflis Kosasih, Profesi Keguruan: 15) 